\title{
4. A COOPERATIVE STUDY OF UPPER-OCEAN PARTICULATE FLUXES IN THE WEDDELL SEA 1
}

\author{
D. C. Biggs, ${ }^{2}$ S. P. Berkowitz, ${ }^{2}$ M. A. Altabet,${ }^{3}$ R. R. Bidigare, ${ }^{4}$ D. J. DeMaster, ${ }^{5}$ R. B. Dunbar, ${ }^{6}$ A. Leventer, ${ }^{6}$ \\ S. A. Macko, ${ }^{7}$ C. A. Nittrouer, ${ }^{8}$ and M. E. Ondrusek ${ }^{4}$
}

\begin{abstract}
During Leg 113, a drifting sediment-trap array was deployed to investigate the flux of natural particulate materials from Weddell Sea summer surface waters. This array was launched, tracked, and recovered from the ice-escort vessel Maersk Master, rather than from the JOIDES Resolution drillship, to carry out these upper-ocean studies without interfering with drilling operations. The arrangement proved highly successful, allowing particle traps to be deployed on 16 occasions for 23-59 hr each during the course of the Maersk Master's ice-tending duties. This paper describes the field program and archives data on the geochemical and biochemical constituents of the material that was trapped. Mass fluxes out of the upper $100 \mathrm{~m}$ averaged $12 \mathrm{mg} / \mathrm{m}^{2} / \mathrm{hr}$, with the highest fluxes trapped near Site $695\left(90 \mathrm{mg} / \mathrm{m}^{2} / \mathrm{hr}\right)$. The trapped material was mostly flocculate in appearance, with microplankton assemblages dominated by diatoms of the genera Nitzschia and Thalassiosira and by the foraminifer Neogloboquadrina pachyderma. The material averaged $28 \%$ biogenic silica by weight; the organic portion was rich in amino acids, with average organic carbon/organic nitrogen ratio (by moles) of $7 \pm 2$. Organic carbon isotopic fractionation $\left(\delta^{13} \mathrm{C}\right)$ ranged from -27 to -31 ; that of organic nitrogen $\left(\delta^{15} \mathrm{~N}\right)$ ranged from -2 to +7 .
\end{abstract}

\section{INTRODUCTION}

The primary mission of the Maersk Master was to ensure the safety of JOIDES Resolution during passage between sites and while drilling on location. Although the seasonal sea-ice cover had retreated from all Leg 113 sites by late January to early February (see Fig. 1), "bergy bits," "growlers," and icebergs were often present. Thus, the ice-escort vessel spent most of its time scouting ahead and prop-washing and/or towing icebergs in the immediate region of the drillship.

When ice conditions were favorable, permission was given to the escort vessel to deploy sediment traps, and/or to run transects to acquire underway magnetic data. Two geophysicists (L. Lawver and M. Lonsdale; see "Underway Geophysics" chapter, this volume) were aboard the Maersk Master to carry out the magnetic program, while S. Berkowitz carried out the sedimenttrapping program.

\section{EQUIPMENT}

We assembled three floating sediment-trap arrays using commercially available mooring line, flotation spheres, radio beacons, and strobes; traps and spar buoys were built at Rice and Texas A\&M Universities, respectively. On each array, two traps were suspended below the primary flotation sphere on braided

\footnotetext{
${ }^{1}$ Barker, P. F., Kennett, J. P., et al., 1988. Proc. Init. Repts. (Pt. A), ODP, 113, College Station, TX (Ocean Drilling Program).

2 Department of Oceanography, Texas A\&M University, College Station, TX 77843.

3 Department of Chemistry, Woods Hole Oceanographic Institution, Woods Hole, MA 02543.

${ }^{4}$ Geochemical and Environmental Research Center, Texas A\&M University, College Station, TX 77843 .

5 Department of Marine, Earth and Atmospheric Sciences, North Carolina State University, Raleigh, NC 27695.

${ }^{6}$ Department of Geology and Geophysics, Rice University, Houston, TX 77251 .

${ }^{7}$ Department of Earth Sciences, Memorial University of Newfoundland, St. Johns, Newfoundland A1B 3X5, Canada.

${ }^{8}$ Marine Sciences Research Center, State University of New York, Stony Brook, New York 11794.
}

nylon mooring line, to which we tethered a spar buoy outfitted with radio beacon, strobe, radar reflector, and flag (Fig. 2). The shallow trap was at $100 \mathrm{~m}$, within the "winter water" temperature minimum (about $-1^{\circ} \mathrm{C}$ ), while the deeper trap was below this temperature minimum zone, at $200 \mathrm{~m}$.

The radio beacon (Novatech model RF700B) broadcast at a VHF frequency of $156 \mathrm{MHz}$ allowing it to be tracked at least 11$13 \mathrm{~km}$ away from the ship, using channel 68 of the commercial RDF unit on the bridge of the Maersk Master (Furuno model FD-525). The net drift of the array was determined from position fixes for deployment and recovery, obtained from the ship's satellite navigation system (Shipmate RS5000 DS receiver).

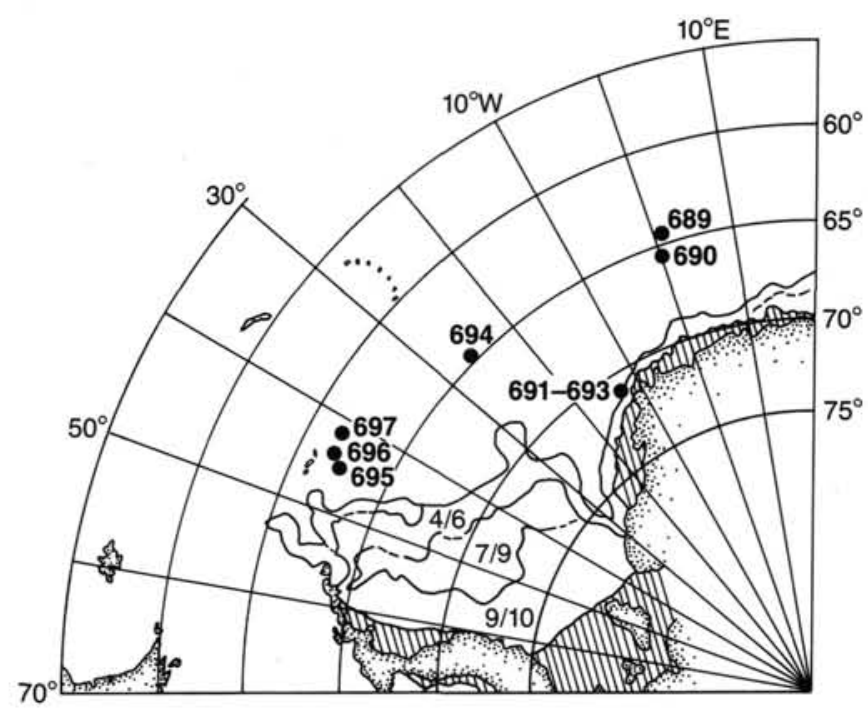

Figure 1. Pack-ice coverage (in tenths) for the Weddell Sea sector of the Southern Ocean in late January 1987, from summary of the Northern Ice Limit compiled by the Navy-NOAA Joint Ice Center in Suitland, Maryland, from NOAA- 9 satellite imagery of 21 and 28 January 1987. Pack-ice code $4 / 6=4$ to 6 tenths; $7 / 9=7$ to 9 tenths, etc. Fast ice along the continental margin is indicated by diagonal lines. 


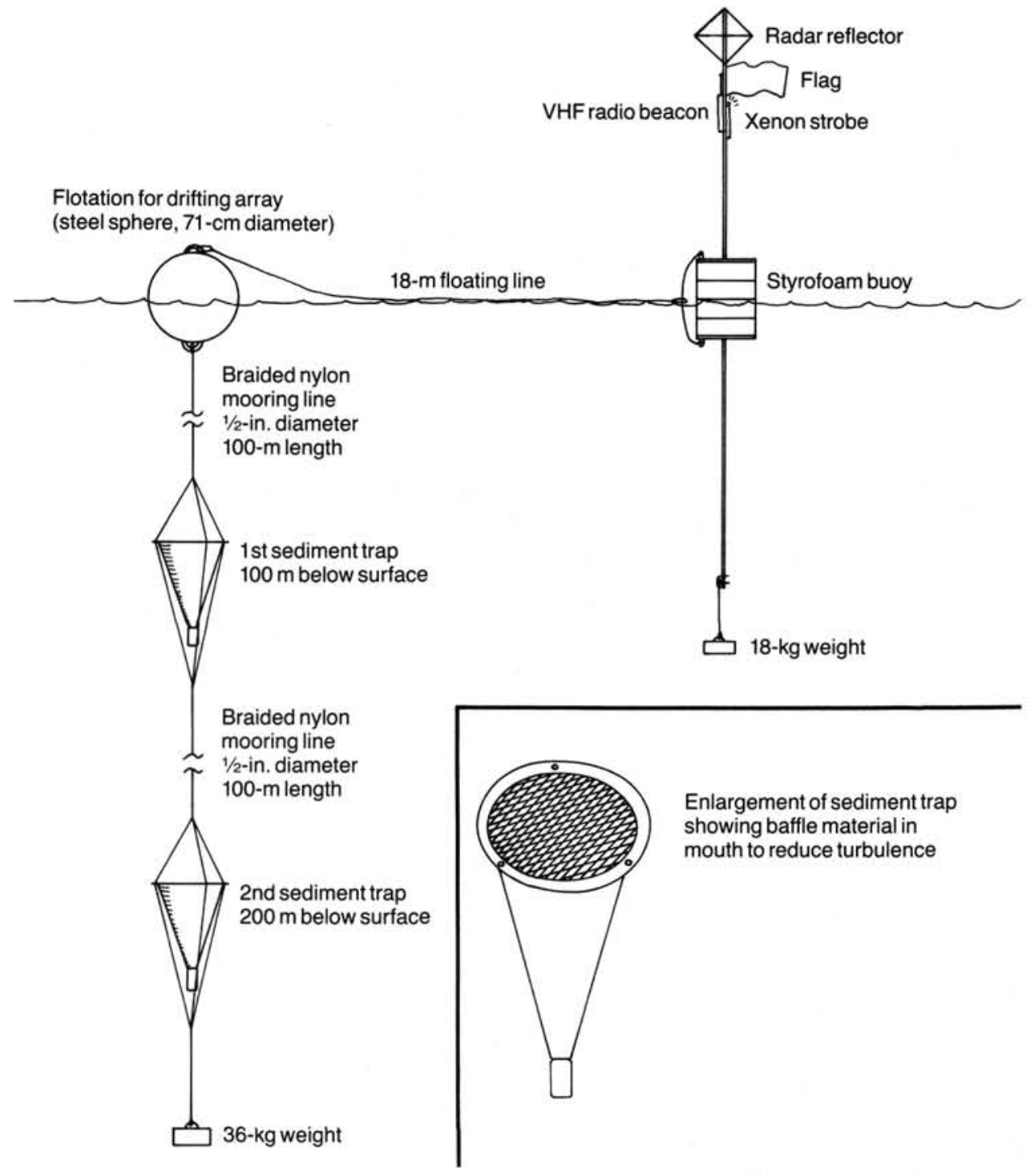

Figure 2. Schematic drawing of drifting sediment-trap array.

Our traps were nonclosing, gel-coated fiberglass cones of Rice University design (Dunbar, 1984), which are inexpensive to fabricate, simple to operate, and easy to service on deck. These cones have a collecting cross section of $1600 \mathrm{~cm}^{2}$, which is baffled with carbon fiber honeycomb material having cells $1 \mathrm{~cm}$ wide by $4 \mathrm{~cm}$ deep. The Rice University design is based on traps built by A. Soutar (Scripps Institution of Oceanography), one of four designs used in a calibration experiment in the Santa Barbara Basin in 1979 (Dymond et al., 1981). Following that experiment, the Soutar trap was chosen as the simplest, most reliable sediment trap designed to collect large samples and was used extensively by the Manganese Nodule Project (MANOP).

Laboratory studies had indicated that the baffle at the mouth of the trap prevents the penetration of turbulent eddies into the trapping chamber, which our field experience on Leg 113 confirmed. Flocculate material in the collecting chamber at the base of the cone was not resuspended back into the cone, even when traps surged near the surface during recovery in seas running 2-3 m. We put valved holes in the side of the cone so that most of the water over the collection jar drained off as the traps were hoisted aboard the ship.

\section{SEDIMENT-TRAP SAMPLING}

Generally good weather during Leg 113 allowed us to achieve our principal goal of collecting consecutive, multiday records of austral summer upper-ocean particulate fluxes. We recovered and then on the same day redeployed arrays in four of the operations regions: (1) two consecutive collections near Site 690 Maud Rise; (2) five consecutive collections near Sites 691-693 at the Dronning Maud Land margin; (3) two consecutive collections near Site 694 on the Weddell abyssal plain; and (4) four consecutive collections near Site 696 on the South Orkney Islands microcontinent. In addition, we made 1-day deployments near Sites 689 and 695.

Arrays were released 4-9 km away from the drillship, and they drifted on average $5 \mathrm{~km}(2.7 \mathrm{n} \mathrm{mi})$ per day. Table 1 gives details of these deployments, sample-coded to indicate the leg-daymonth-depth of sample recovery. We had two logistics problems: (1) the 200-m trap from our fifth deployment off Dronning Maud Land (collection 113-05-February (F)-Deep (D), near Site 693) fell to the deck when a line slacked during recovery, spilling perhaps half of its contents; (2) the 100-m trap from our second 
Table 1. Summary of drifting sediment-trap array deployments during Leg 113. Sample code gives leg-date-month that each array was recovered.

\begin{tabular}{|c|c|c|c|c|c|}
\hline Sample code & $\begin{array}{l}\text { Operations area } \\
\text { (Site) }\end{array}$ & $\begin{array}{l}\text { Deployment } \\
\text { location }\end{array}$ & $\begin{array}{l}\text { Recovery } \\
\text { location }\end{array}$ & $\begin{array}{l}\text { Duration } \\
(\mathrm{hr})\end{array}$ & Net drift \\
\hline 113-18 Jan & 689 & $\begin{array}{l}64^{\circ} 36.8^{\prime} \mathrm{S} \\
03^{\circ} 05.0^{\prime} \mathrm{E}\end{array}$ & $\begin{array}{l}64^{\circ} 36.0^{\prime} \mathrm{S} \\
02^{\circ} 56.9^{\prime} \mathrm{E}\end{array}$ & 23.3 & $\begin{array}{l}6.7 \mathrm{~km} \\
(3.6 \mathrm{n} \mathrm{mi}) \\
\text { set } 290^{\circ}\end{array}$ \\
\hline 113-21 Jan & 690 & $\begin{array}{l}65^{\circ} 16.6^{\prime} \mathrm{S} \\
01^{\circ} 12.9^{\prime} \mathrm{E}\end{array}$ & $\begin{array}{l}65^{\circ} 14.0^{\prime} \mathrm{S} \\
01^{\circ} 10.0^{\prime} \mathrm{E}\end{array}$ & 24.3 & $\begin{array}{l}5.9 \mathrm{~km} \\
(3.2 \mathrm{n} \mathrm{mi}) \\
\text { set } 335^{\circ}\end{array}$ \\
\hline 113-22 Jan & 690 & $\begin{array}{l}65^{\circ} 14.0^{\prime} \mathrm{S} \\
01^{\circ} 10.0^{\prime} \mathrm{E}\end{array}$ & $\begin{array}{l}65^{\circ} 13.3^{\prime} \mathrm{S} \\
01^{\circ} 08.5^{\prime} \mathrm{E}\end{array}$ & 28.3 & $\begin{array}{l}1.5 \mathrm{~km} \\
(0.8 \mathrm{n} \mathrm{mi}) \\
\text { set } 315^{\circ}\end{array}$ \\
\hline 113-29 Jan & 692 & $\begin{array}{c}70^{\circ} 45.5^{\prime} \mathrm{S} \\
13^{\circ} 48.5^{\prime} \mathrm{W}\end{array}$ & $\begin{array}{c}70^{\circ} 47.3^{\prime} \mathrm{S} \\
13^{\circ} 59.5^{\prime} \mathrm{W}\end{array}$ & 25.8 & $\begin{array}{l}7.4 \mathrm{~km} \\
(4.0 \mathrm{n} \mathrm{mi}) \\
\text { set } 245^{\circ}\end{array}$ \\
\hline $113-01 \mathrm{Feb}$ & 693 & $\begin{array}{c}70^{\circ} 54.3^{\prime} \mathrm{S} \\
14^{\circ} 37.5^{\prime} \mathrm{W}\end{array}$ & $\begin{array}{l}71^{\circ} 04.0^{\prime} \mathrm{S} \\
14^{\circ} 43.0^{\prime} \mathrm{W}\end{array}$ & 44.0 & $\begin{array}{l}17.8 \mathrm{~km} \\
(9.6 \mathrm{n} \mathrm{mi}) \\
\text { set } 190^{\circ}\end{array}$ \\
\hline $113-02 \mathrm{Feb}$ & 693 & $\begin{array}{c}70^{\circ} 53.0^{\prime} \mathrm{S} \\
14^{\circ} 36.0^{\prime} \mathrm{W}\end{array}$ & $\begin{array}{l}70^{\circ} 55.5^{\prime} \mathrm{S} \\
14^{\circ} 44.0^{\prime} \mathrm{S}\end{array}$ & 29.2 & $\begin{array}{l}6.1 \mathrm{~km} \\
(3.3 \mathrm{n} \mathrm{mi}) \\
\text { set } 230^{\circ}\end{array}$ \\
\hline $113-04 \mathrm{Feb}$ & 693 & $\begin{array}{c}70^{\circ} 54.8^{\prime} \mathrm{S} \\
14^{\circ} 46.0^{\prime} \mathrm{W}\end{array}$ & $\begin{array}{c}70^{\circ} 57.0^{\prime} \mathrm{S} \\
14^{\circ} 46.0^{\prime} \mathrm{W}\end{array}$ & 39.3 & $\begin{array}{l}4.1 \mathrm{~km} \\
(2.2 \mathrm{n} \mathrm{mi}) \\
\text { set } 180^{\circ}\end{array}$ \\
\hline $113-05 \mathrm{Feb}$ & 693 & $\begin{array}{c}70^{\circ} 52.0^{\prime} \mathrm{S} \\
14^{\circ} \\
36.0^{\prime} \mathrm{W}\end{array}$ & $\begin{array}{c}70^{\circ} 56.5^{\prime} \mathrm{S} \\
14^{\circ} 46.0^{\prime} \mathrm{W}\end{array}$ & 26.7 & $\begin{array}{l}10.7 \mathrm{~km} \\
(5.8 \mathrm{n} \mathrm{mi}) \\
\text { set } 215^{\circ}\end{array}$ \\
\hline $113-11 \mathrm{Feb}$ & 694 & $\begin{array}{l}66^{\circ} 49.0^{\prime} \mathrm{S} \\
33^{\circ} 29.0^{\prime} \mathrm{W}\end{array}$ & $\begin{array}{l}66^{\circ} 56.0^{\prime} \mathrm{S} \\
33^{\circ} 26.0^{\prime} \mathrm{W}\end{array}$ & 33.6 & $\begin{array}{l}13.1 \mathrm{~km} \\
(7.1 \mathrm{n} \mathrm{mi}) \\
\text { set } 170^{\circ}\end{array}$ \\
\hline $113-15 \mathrm{Feb}$ & 694 & $\begin{array}{l}66^{\circ} 51.8^{\prime} \mathrm{S} \\
33^{\circ} 23.0^{\prime} \mathrm{W}\end{array}$ & $\begin{array}{c}66^{\circ} 53.0^{\prime} \mathrm{S} \\
33^{\circ} 09.0^{\prime} \mathrm{W}\end{array}$ & 26.3 & $\begin{array}{l}10.2 \mathrm{~km} \\
(5.5 \mathrm{n} \mathrm{mi}) \\
\text { set } 095^{\circ}\end{array}$ \\
\hline $113-17 \mathrm{Feb}$ & 694 & $\begin{array}{l}66^{\circ} 51.8^{\prime} \mathrm{S} \\
33^{\circ} 23.0^{\prime} \mathrm{W}\end{array}$ & $\begin{array}{c}66^{\circ} 49.0^{\prime} \mathrm{S} \\
33^{\circ} 20.0^{\prime} \mathrm{W}\end{array}$ & 58.8 & $\begin{array}{l}5.9 \mathrm{~km} \\
(3.2 \mathrm{n} \mathrm{mi}) \\
\text { set } 020^{\circ}\end{array}$ \\
\hline $113-22 \mathrm{Feb}$ & 695 & $\begin{array}{c}62^{\circ} 24.0^{\prime} \mathrm{S} \\
43^{\circ} 23.0^{\prime} \mathrm{W}\end{array}$ & $\begin{array}{l}62^{\circ} 22.1^{\prime} \mathrm{S} \\
43^{\circ} 21.8^{\prime} \mathrm{W}\end{array}$ & 29.2 & $\begin{array}{l}3.7 \mathrm{~km} \\
(2.0 \mathrm{n} \mathrm{mi}) \\
\text { set } 010^{\circ}\end{array}$ \\
\hline $113-24 \mathrm{Feb}$ & 696 & $\begin{array}{c}61^{\circ} 49.2^{\prime} \mathrm{S} \\
42^{\circ} 55.7^{\prime} \mathrm{W}\end{array}$ & $\begin{array}{c}61^{\circ} 40.0^{\prime} \mathrm{S} \\
42^{\circ} 46.0^{\prime} \mathrm{W}\end{array}$ & 24.0 & $\begin{array}{l}8.7 \mathrm{~km} \\
(4.7 \mathrm{n} \mathrm{mi}) \\
\text { set } 085^{\circ}\end{array}$ \\
\hline $113-26 \mathrm{Feb}$ & 696 & $\begin{array}{c}61^{\circ} 49.2^{\prime} \mathrm{S} \\
42^{\circ} 55.7^{\prime} \mathrm{W}\end{array}$ & $\begin{array}{l}61^{\circ} 45.5^{\prime} \mathrm{S} \\
42^{\circ} 48.2^{\prime} \mathrm{W}\end{array}$ & 42.8 & $\begin{array}{l}9.6 \mathrm{~km} \\
(5.2 \mathrm{n} \mathrm{mi}) \\
\text { set } 050^{\circ}\end{array}$ \\
\hline $113-27 \mathrm{Feb}$ & 696 & $\begin{array}{c}61^{\circ} 49.2^{\prime} \mathrm{S} \\
42^{\circ} 55.7^{\prime} \mathrm{W}\end{array}$ & $\begin{array}{c}61^{\circ} 49.0^{\prime} \mathrm{S} \\
42^{\circ} 50.5^{\prime} \mathrm{W}\end{array}$ & 27.5 & $\begin{array}{l}4.6 \mathrm{~km} \\
(2.5 \mathrm{n} \mathrm{mi}) \\
\text { set } 085^{\circ}\end{array}$ \\
\hline 113-01 Mar & 696 & $\begin{array}{c}61^{\circ} 49.2^{\prime} \mathrm{S} \\
42^{\circ} 55.7^{\prime} \mathrm{W}\end{array}$ & $\begin{array}{l}61^{\circ} 49.0^{\prime} \mathrm{S} \\
42^{\circ} 50.0^{\prime} \mathrm{W}\end{array}$ & 24.8 & $\begin{array}{l}5.4 \mathrm{~km} \\
(2.9 \mathrm{n} \mathrm{mi}) \\
\text { set } 085^{\circ}\end{array}$ \\
\hline
\end{tabular}

deployment near Site 696 (collection 113-26-F-Shallow (S)) was recovered with one cable of its three-part, upper bridle broken. If it hung at an angle to the downline during some or all of the 43-hr deployment, it probably undertrapped material.

Each time that the traps were recovered, samples were scanned under a dark-field binocular microscope for the presence of "swimmers," because inadvertently trapped vertical migrators will bias estimates of upper-ocean particulate flux (Harbison and Gilmer, 1986). However, on Leg 113 such "swimmers" were rarely trapped during our short-term deployments (never more than one to two pteropods or one to two copepods per trap; these were removed and pickled separately).

After scanning, samples were split with a Motoda-style plankton splitter to $1 / 4$ or $1 / 8$ aliquots. One aliquot was archived in $10 \%$ buffered Formalin, while the others were filtered for postcruise determination of their geochemical and biochemical constituents. For determination of biogenic silica content, 1/4 splits were filtered onto preweighed Nucleopore $0.4-\mu \mathrm{m}$ polycarbonate filters, which were then dried at $60^{\circ} \mathrm{C}$ for $24 \mathrm{hr}$. For determination of organic content and its carbon and nitrogen isotopic fractionation, $1 / 4$ splits (or $1 / 8$ splits when material was abundant) were filtered onto precombusted Whatman GF/F fil- ters, which were also dried at $60^{\circ} \mathrm{C}$ for $24 \mathrm{hr}$. For determination of plant pigments and their degradation products, $1 / 4$ splits were filtered onto Nucleopore $0.4-\mu \mathrm{m}$ polyester filters, which were then frozen and transported on ice.

To evaluate the precision of the onboard splitting technique, several replicate splits were processed from the shallow (S) trap at $100 \mathrm{~m}$ at station $113-22-\mathrm{F}$ after visual inspection showed that it had collected more than an average amount of material. Table 2 shows that both dry weight and biogenic silica determined separately on two $1 / 16$ splits agreed to within $2 \%$. The other chemical analyses also showed good agreement between replicate splits. For example, the three most abundant plant pigments and their degradation products in a 1/32 split of sample $113-22-\mathrm{F}-\mathrm{S}$ were present at $56 \%, 51 \%$, and $57 \%$ of their concentrations in a 1/16 split and the total weight of all 14 pigments that were resolved in the $1 / 32$ split was $53 \%$ of their total weight in the $1 / 16$ split.

\section{BUCKET SAMPLING}

Surface water samples were collected daily by bucket to give a general impression of phytoplankton standing stocks. One liter of each was filtered through a Whatman GF/F filter and then 
Table 2. Mass flux and biogenic silica flux, calculated from $1 / 4$ splits of the total trapped material (or from a pair of 1/16 splits, 100-m sample 22-F-S). Sample code lists datemonth-trap depth (S, shallow or $\mathrm{D}$, deep).

\begin{tabular}{|c|c|c|c|c|c|}
\hline $\begin{array}{l}\text { Sample } \\
\text { code }\end{array}$ & $\begin{array}{l}\text { Weight on } \\
\text { filter } \\
\text { (mg) }\end{array}$ & $\begin{array}{l}\text { Dissolved }\left(\mathrm{SiO}_{2}\right) \\
\text { in } 50 \text {-mL extract } \\
\text { solution }(\mu \mathrm{mol})\end{array}$ & $\begin{array}{c}\text { Wt \% biogenic } \\
\mathrm{SiO}_{2}\end{array}$ & $\begin{array}{l}\text { Mass flux } \\
\left(\times 10^{-7}\right. \\
\left.\mathrm{g} / \mathrm{cm}^{2} / \mathrm{hr}\right)\end{array}$ & $\begin{array}{c}\text { Biogenic } \mathrm{SiO}_{2} \\
\text { flux }\left(\times 10^{-10}\right. \\
\left.\mathrm{mol} / \mathrm{cm}^{2} / \mathrm{hr}\right)\end{array}$ \\
\hline 113-18-J-S & 2.93 & 76 & 7.8 & 3.2 & 4.2 \\
\hline 113-18-J-D & 7.97 & 45 & 1.7 & 8.6 & 2.4 \\
\hline $113-21-\mathrm{J}-\mathrm{S}$ & 1.85 & 80 & 13 & 1.9 & 4.1 \\
\hline 113-21-J-D & 2.38 & 56 & 7.0 & 2.4 & 2.8 \\
\hline $113-22-\mathrm{J}-\mathrm{S}$ & 2.20 & 138 & 19 & 2.0 & 6.3 \\
\hline 113-22-J-D & 1.54 & 28 & 5.5 & 1.4 & 1.3 \\
\hline 113-29-J-S & 9.68 & 234 & 7.2 & a & 11 \\
\hline 113-29-J-D & 65.76 & 162 & 0.7 & a & 7.6 \\
\hline $113-01-\mathrm{F}-\mathrm{S}$ & 44.69 & 2750 & 19 & 25.4 & 80 \\
\hline 113-01-F-D & 10.58 & 710 & 20 & 6.0 & 20 \\
\hline 113-02-F-S & 10.29 & 1320 & 38 & 8.8 & 56 \\
\hline $113-02-\mathrm{F}-\mathrm{D}$ & 7.38 & 323 & 13 & 6.3 & 14 \\
\hline $113-04-\mathrm{F}-\mathrm{S}$ & 14.53 & 1590 & 33 & 9.2 & 51 \\
\hline 133-04-F-D & 22.53 & 1400 & 19 & 14.3 & 45 \\
\hline $113-05-\mathrm{F}-\mathrm{S}$ & 16.49 & 1840 & 34 & 15.4 & 87 \\
\hline 113-05-F-D & 6.47 & 625 & 29 & 6.1 & 29 \\
\hline 113-11-F-S & 1.37 & 104 & 23 & 1.0 & 3.8 \\
\hline 113-11-F-D & 3.43 & 56 & 4.9 & 2.6 & 2.1 \\
\hline 113-15-F-S & 2.96 & 117 & 12 & 2.8 & 5.6 \\
\hline 113-15-F-D & ND & 38 & - & - & 1.8 \\
\hline 113-17-F-S & 3.19 & 244 & 23 & 1.4 & 5.4 \\
\hline 113-17-F-D & 1.52 & 52 & 10 & 0.6 & 1.0 \\
\hline 113-22-F-Sa & 25.59 & 6130 & 72 & 87.7 & 1050 \\
\hline 113-22-F-Sb & 26.55 & 6000 & 68 & 91.0 & 1030 \\
\hline 113-22-F-D & 15.70 & 3310 & 63 & 13.4 & 141 \\
\hline $113-24-F-S$ & 5.84 & 1060 & 55 & 6.1 & 56 \\
\hline 113-24-F-D & 3.80 & 607 & 48 & 4.0 & 32 \\
\hline $113-26-\mathrm{F}-\mathrm{S}$ & 4.53 & 515 & 34 & 2.6 & 15 \\
\hline 113-26-F-D & 2.40 & 254 & 32 & 1.4 & 7.5 \\
\hline $113-27-F-S$ & 4.55 & 652 & 43 & 4.1 & 29 \\
\hline 113-27-F-D & 8.16 & 433 & 16 & 7.4 & 20 \\
\hline 113-01-M-S & 9.36 & 590 & 19 & 9.4 & 30 \\
\hline 113-01-M-D & 3.24 & 251 & 23 & 3.3 & 13 \\
\hline
\end{tabular}

${ }^{\text {a }}$ Rust in samples $29 \mathrm{~J}-\mathrm{S}$ and $29 \mathrm{~J}-\mathrm{D}$ biased calculation of mass flux.

extracted overnight at $0^{\circ} \mathrm{C}$ in $90 \%$ acetone for the "Turner" fluorometric determination of total chlorophyll plus phaeopigments (see sections 4.3 and 4.4 in Parsons et al, 1985).

As Table 3 shows, chlorophyll in bucket samples generally measured less than $0.05 \mu \mathrm{g} / \mathrm{L}$, two orders of magnitude less than algal "bloom" concentrations. However, surface chlorophyll was double the regional average near Site 695 and near Site 693 , and our traps collected greater amounts of material near these sites than near the others visited on Leg 113. This may reflect neritic influence, since Site 695 lies close to the South Orkney Islands shelf/slope break, while Site 693 lies within $110 \mathrm{~km}$ of the Kronprinsesse Martha Coast of continental Dronning Maud Land. It may also reflect the fact that both of these sites had more recently been covered by pack-ice than had the other regions. Analysis of weekly summary Northern Ice Limit charts prepared by the U.S. Navy-NOAA Joint Ice Center in Suitland, Maryland, shows that the seasonal sea ice had melted back from Site 693 between 8 and 15 January 1987, only about 2 weeks before we trapped there. The pack had melted back from Site 695 about this same time, or 6 weeks before we trapped there. By contrast, the other South Orkney platform sites and the Maud Rise sites had been in open water since mid-December 1986.

\section{MASS FLUXES AND BIOGENIC SILICA FLUXES}

(Analyses by D. J. DeMaster and C. A. Nittrouer)

After determining the weight of material on the filters, the samples were placed in individual $50-\mathrm{mL}$ centrifuge tubes and an $85^{\circ} \mathrm{C} 0.2 \mathrm{~N} \mathrm{NaOH}$ solution was added. The centrifuge tubes were then placed in an $85^{\circ} \mathrm{C}$ water bath for $2 \mathrm{hr}$, and the amount of biogenic silica leached by the alkaline solution was determined according to the procedure described by DeMaster (1981).

\section{Results}

The mass flux in the surface traps averaged $12 \times 10^{-7} \mathrm{~g} /$ $\mathrm{cm}^{2} / \mathrm{hr}$ with values ranging from 1.0 to $91 \times 10^{-7} \mathrm{~g} / \mathrm{cm}^{2} / \mathrm{hr}$ (Table 3). The ratio of the mass flux in the 200-m trap to the mass flux in the $100-\mathrm{m}$ trap varied from 0.15 to 2.7 , with a mean value of 1.0. The highest mass fluxes occurred at Sites 695 and 693.

Biogenic silica contents in the 100 -m trap varied from $8 \%$ to $72 \%$ with a mean value of $28 \%$. Unlike the mass fluxes, the weight percent biogenic silica content in the $200-\mathrm{m}$ traps was almost always less than that observed in the $100-\mathrm{m}$ traps. The mean ratio of biogenic silica content in the 200 -m traps to that in the $100-\mathrm{m}$ traps was 0.6 , with values ranging from 0.1 to 1.2 . The biogenic silica fluxes in the $100-\mathrm{m}$ traps varied from 4 to $1050 \times 10^{-10} \mathrm{~mol} / \mathrm{cm}^{2} / \mathrm{hr}$, with a mean value of $90 \times 10^{-10}$ $\mathrm{mol} / \mathrm{cm}^{2} / \mathrm{hr}$.

The ratio of the biogenic silica flux in the 200-m trap to the flux in the 100 -m trap averaged 0.45 , very similar to the pattern observed for mean biogenic silica content. The highest biogenic silica fluxes occurred at the sites that had the highest mass fluxes (Sites 695 and 693).

\section{PARTICULATE ORGANIC CONTENT AND $\delta^{13} \mathrm{C}$ AND $\delta^{15} \mathbf{N}$ ISOTOPIC COMPOSITION}

(Analyses by S. A. Macko and M. A. Altabet) 


\section{Methods-Memorial University of Newfoundland}

The pre-ashed filters and samples were acidified with $30 \%$ $\mathrm{HCl}$ to remove carbonate and dried at $40^{\circ} \mathrm{C}$. The filters were then broken into small fragments and mixed with an excess of purified $\left(850^{\circ} \mathrm{C}, 1 \mathrm{hr}\right)$ coarsely-ground cupric oxide (BDH Chemical) and pure granular copper (Alpha Resources Inc.) for a modified Dumas combustion (Macko, 1981). The mixed samples were placed in pre-combusted quartz tubes, which were evacuated, sealed, combusted for $1 \mathrm{hr}$ at $850^{\circ} \mathrm{C}$, and then slowly cooled. The $\mathrm{N}_{2}$ and $\mathrm{CO}_{2}$ combustion products were cryogenically purified and collected. The carbon and nitrogen isotope compositions were determined on a triple-collector, stable-isotope-ratio, V.G. Micromass $903 \mathrm{E}$ mass spectrometer. Isotopic compositions are reported as:

$$
\delta=\left[\frac{\mathrm{R}_{\text {Sample }}}{\mathrm{R}_{\text {Standard }}}-1\right] \times 10^{3}
$$

where $\mathrm{R}$ is the abundance ratio of the heavy to light isotope. The $\delta^{13} \mathrm{C}$ values are reported relative to the Chicago PDB, and the $\delta^{15} \mathrm{~N}$ values are relative to atmospheric nitrogen gas.

\section{Methods-Woods Hole Oceanographic Institution}

At WHOI, a similar in-vacuo Dumas combustion technique was utilized to examine the fractionation of ${ }^{15} \mathrm{~N}$ in particulate matter, along with the ${ }^{15} \mathrm{~N}$ signature of the filtrate from selected sites (nitrate, plus other dissolved inorganic nitrogen species). After they were acid-fumed to remove carbonates, the particulate samples were placed in evacuated quartz ampoules with $\mathrm{CuO}, \mathrm{Cu}$, and $\mathrm{Ag}$ (foil), and then were sealed and combusted at $850^{\circ} \mathrm{C}$. Nitrogen gas was purified from the other combustion products offline and condensed onto a molecular sieve at the temperature of liquid nitrogen into a sample container. The samples were then run on a Finigan 251 mass spectrometer with atmospheric nitrogen gas as a standard.

Filtrate samples (which had been stored in cubetainers after stabilization aboard ship with $\mathrm{HCl}$ to a final concentration of $0.5 \% \mathrm{v} / \mathrm{v})$ were processed similarly; after converting their nitrate to $\mathrm{NH}_{3}$ using Devarda's alloy, the $\mathrm{NH}_{3}$ was distilled off and collected onto an ion sieve, which after drying was handled as particulate samples were.

\section{Results-Memorial University of Newfoundland and Woods Hole Oceanographic Institution}

As is evident from Tables 4 and 5, the particulate organic content of the trapped material was quite low. Because the organic nitrogen content in particular seldom exceed $100 \mu \mathrm{g}$ per split, there was some discrepancy between our two laboratories in the determination of total PON and of its nitrogen isotopic fractionation which may reflect instrumental limitation at very small sample sizes. Each laboratory experienced instances in which samples were lost in combustion or in purification, or were simply too small to determine nitrogen isotopic composition.

With this in mind, although individual ${ }^{15} \mathrm{~N}$ analyses ranged from -2.1 to +3.5 in Table 4 and from -1.2 to +7.8 in Table 5 , the mean degree of ${ }^{15} \mathrm{~N}$ fractionation reported in Table 4 (mean $=0.6 \pm 1.9$ per mil, $\mathrm{n}=11$ ) is not different statistically from that in Table 5 (mean $\delta^{15} \mathrm{~N}=2.5 \pm 2.6$ per mil, for splits from the same 11 samples).

However, the ensemble mean $\delta^{15} \mathrm{~N}$ value for all of the sediment trap samples ( $2 \pm 2$ per mil, $n=28)$ is obviously lower than the average $\delta^{15} \mathrm{~N}$ measured for nitrate in Weddell Sea surface waters ( $8 \pm 1$ per mil; see Table 5$)$. This is consistent with the paradigm that isotopic fractionation in $\mathrm{PON}$ is most evident when nitrate is abundant in surface waters (Altabet and McCarthy, 1985). In contrast, the tendency for $\delta^{15} \mathrm{~N}$ to increase between $100 \mathrm{~m}$ and $200 \mathrm{~m}$ combined with a sharp decrease in $\mathrm{N}$ flux between $100 \mathrm{~m}$ and $200 \mathrm{~m}$ at almost all sites suggests that there was rapid degradation of the organic nitrogen sinking out of surface waters.

Both the carbon isotopic fractionation data and the average $\mathrm{C} / \mathrm{N}$ ratio of the trapped material indicate that at all sites the organic materials were typical of marine pelagic biogenic material. Table 4 shows that $\delta^{13} \mathrm{C}$ for particulate organic carbon (POC) averaged $-29 \pm 1$, while the $\mathrm{C} / \mathrm{N}$ ratio averaged $7 \pm 2$.

\section{AMINO ACID COMPOSITION}

\section{(Analyses by S. A. Macko)}

From selected sites, subsamples from seven of the samples filtered for $\mathrm{C}$ and $\mathrm{N}$ isotopic studies were placed in precombusted digestion tubes with teflon-lined caps. One milliliter of quartz-distilled $6 \mathrm{~N} \mathrm{HCl}$ was added to each sample. The tubes were sealed under $\mathrm{N}_{2}$ and heated at $100^{\circ} \mathrm{C}$ for $24 \mathrm{hr}$. An aliquot of the acid liquor was then evaporated to dryness and dissolved in buffer for injection into an amino acid analyzer. Separation of the amino acids was by high-performance liquid chromatographic (HPLC) ion exchange chromatography with post-column derivatization with ortho-phthaldehyde and fluorescence detection and integration (Hare, 1972). A cation exchange 3- $\mu \mathrm{m}$ resin column was used with stepwise isocratic elution.

\section{Results}

Amino acid analysis shows that the organic material on all filters is rich in amino acids, with essentially all of the nitrogen represented by amino nitrogen (Table 6). In general, a decrease in amino acid content is seen between the $100-\mathrm{m}$ and $200-\mathrm{m}$ traps, correlating with the general decrease in organic loading. Little difference in the amino acid signature of the organic material was observed between deployments, locations, or trap depths. A slight decrease in short-chain neutral amino acids with a concurrent increase in basic amino acids, however, can be observed when the material trapped at $100 \mathrm{~m}$ is compared with that trapped at $200 \mathrm{~m}$ (station 113-04-F, near Site 693).

\section{PLANT PIGMENTS AND THEIR DEGRADATION PRODUCTS}

(Analyses by R. R. Bidigare and M. E. Ondrusek)

Sediment-trap splits were extracted in $2-\mathrm{mL} 90 \%$ acetone for at least $48 \mathrm{hr}$ (in the dark at $-10^{\circ} \mathrm{C}$ ) and centrifuged for $5 \mathrm{~min}$ to remove cellular debris. Previously described HPLC methodology (Bidigare et al., 1985) has been modified to provide separation of the major carotenoid accessory pigments and chlorophyll a derivatives.

HPLC was performed with a Spectra-Physics SP8100 liquid chromatograph and Radial-Pak C18 column at a flow rate of 10 $\mathrm{mL} / \mathrm{min}$. Samples were prepared for injection using the ionpairing agent described by Mantoura and Llewellyn (1983). After injection (500- $\mu \mathrm{L}$ sample), mobile phase A (85:15:5; methanol:water:ion-pairing agent) was ramped to mobile phase B (methanol) over a 12-min period. Mobile phase B was then pumped for $13 \mathrm{~min}$ for a total analysis time of $25 \mathrm{~min}$.

Chlorophyll/carotenoid and phaeopigment peaks were detected with a Waters model 440 fixed wavelength absorbance detector $(436 \mathrm{~nm})$ and Waters $420 \mathrm{AC}$ fluorescence detector (460$\mathrm{nm}$ excitation filter; 600 -nm emission filter), respectively. Peaks were quantified by integration of peak area and the HPLC system was calibrated using available standards. The specific pigments resolved included chlorophylls $\mathrm{a}, \mathrm{b}$, and c; chlorophyllide a; phaeophorbide a; fucoxanthin; 19' hexanoyl-fucoxanthin; diadinoxanthin; zeaxanthin plus lutein; carotene; phaeophytin 
Table 3. Summary of daily bucket sampling from Maersk Master to estimate sea-surface concentration of total chlorophyll + acid degradation products, by onboard fluorometric analysis of pigments extracted in $90 \%$ acetone ("Turner" method). Chlorophyll and phaeopigment concentration units $=\mu \mathrm{g} /$ liter; ND $=$ below limit of detection (less than $0.01 \mu \mathrm{g} /$ liter).

\begin{tabular}{|c|c|c|c|c|c|}
\hline $\begin{array}{c}\text { Date } \\
(1987)\end{array}$ & Latitude & Longitude & Chlorophyll & Phaeopigment & Comments \\
\hline
\end{tabular}

In transit to Maud Rise operations region:

$\begin{array}{llll}12 \mathrm{Jan} & 60^{\circ} 20^{\prime} \mathrm{S} & 28^{\circ} 44^{\prime} \mathrm{W} & 0.05 \\ 13 \mathrm{Jan} & 61^{\circ} 13^{\prime} \mathrm{S} & 16^{\circ} 14^{\prime} \mathrm{W} & 0.04 \\ 14 \mathrm{Jan} & 63^{\circ} 00^{\prime} \mathrm{S} & 08^{\circ} 16^{\prime} \mathrm{W} & 0.02\end{array}$

In Maud Rise region, near Sites 689 and 690:

$\begin{array}{llll}\text { 15 Jan } & 64^{\circ} 23^{\prime} \mathrm{S} & 00^{\circ} 51^{\prime} \mathrm{E} & 0.03 \\ \text { 16 Jan } & 63^{\circ} 44^{\prime} \mathrm{S} & 04^{\circ} 29^{\prime} \mathrm{E} & 0.02 \\ \text { 17 Jan } & 63^{\circ} 54^{\prime} \mathrm{S} & 04^{\circ} 33^{\prime} \mathrm{E} & 0.06 \\ \text { 18 Jan } & 64^{\circ} 30^{\prime} \mathrm{S} & 03^{\circ} 08^{\prime} \mathrm{E} & 0.04 \\ \text { 19 Jan } & 64^{\circ} 31^{\prime} \mathrm{S} & 03^{\circ} 05^{\prime} \mathrm{E} & 0.02 \\ \text { 20 Jan } & 65^{\circ} 07^{\prime} \mathrm{S} & 00^{\circ} 42^{\prime} \mathrm{E} & 0.03 \\ \text { 21 Jan } & 65^{\circ} 19^{\prime} \mathrm{S} & 01^{\circ} 22^{\prime} \mathrm{E} & 0.01 \\ \text { 22 Jan } & 65^{\circ} 02^{\prime} \mathrm{S} & 02^{\circ} 04^{\prime} \mathrm{E} & 0.01 \\ \text { 23 Jan } & 65^{\circ} 10^{\prime} \mathrm{S} & 02^{\circ} 01^{\prime} \mathrm{E} & 0.02 \\ \text { ean surface chlorophyll } & & \overline{0.03} \pm 0.02 \\ \text { near Sites } 689 \text { and } 690: & & \end{array}$

In transit to Dronning Maud Land operations region:

$\begin{array}{lllll}24 \mathrm{Jan} & 66^{\circ} 41^{\prime} \mathrm{S} & 02^{\circ} 28^{\prime} \mathrm{W} & 0.02 & \text { ND } \\ 25 \mathrm{Jan} & 70^{\circ} 10^{\prime} \mathrm{S} & 11^{\circ} 58^{\prime} \mathrm{W} & 0.06 & \text { ND }\end{array}$

In Dronning Maud Land region, near Sites 691-693:

$\begin{array}{cccc}\text { 26 Jan } & 70^{\circ} 46^{\prime} \mathrm{S} & 13^{\circ} 46^{\prime} \mathrm{W} & 0.32 \\ \text { 27 Jan } & 70^{\circ} 43^{\prime} \mathrm{S} & 13^{\circ} 49^{\prime} \mathrm{W} & 0.14 \\ \text { 28 Jan } & 70^{\circ} 46^{\prime} \mathrm{S} & 13^{\circ} 42^{\prime} \mathrm{S} & 0.04 \\ \text { 29 Jan } & 70^{\circ} 11^{\prime} \mathrm{S} & 15^{\circ} 41^{\prime} \mathrm{W} & 0.04 \\ \text { 30 Jan } & 70^{\circ} 52^{\prime} \mathrm{S} & 14^{\circ} 37^{\prime} \mathrm{W} & 0.03 \\ \text { 31 Jan } & 70^{\circ} 50^{\prime} \mathrm{S} & 14^{\circ} 27^{\prime} \mathrm{W} & 0.16 \\ \text { 1 Feb } & 70^{\circ} 56^{\prime} \mathrm{S} & 14^{\circ} 44^{\prime} \mathrm{W} & 0.15 \\ \text { 2 Feb } & 70^{\circ} 47^{\prime} \mathrm{S} & 14^{\circ} 28^{\prime} \mathrm{W} & 0.15 \\ \text { 3 Feb } & 70^{\circ} 51^{\prime} \mathrm{S} & 14^{\circ} 30^{\prime} \mathrm{W} & 0.10 \\ \text { 4 Feb } & 70^{\circ} 52^{\prime} \mathrm{S} & 14^{\circ} 36^{\prime} \mathrm{W} & 0.09 \\ \text { 5 Feb } & 70^{\circ} 50^{\prime} \mathrm{S} & 14^{\circ} 39^{\prime} \mathrm{W} & 0.06 \\ \text { 6 Feb } & 70^{\circ} 52^{\prime} \mathrm{S} & 14^{\circ} 37^{\prime} \mathrm{W} & 0.03 \\ \text { 7 Feb } & 70^{\circ} 51^{\prime} \mathrm{S} & 14^{\circ} 26^{\prime} \mathrm{W} & 0.02 \\ \text { ean surface chlorophyll } & & 0.10 \pm 0.08\end{array}$

In transit to Weddell Abyssal Plain operations region:

$\begin{array}{lllll}8 \mathrm{Feb} & 70^{\circ} 00^{\prime} \mathrm{S} & 19^{\circ} 48^{\prime} \mathrm{W} & 0.01 & \text { ND } \\ 9 \mathrm{Feb} & 67^{\circ} 42^{\prime} \mathrm{S} & 30^{\circ} 45^{\prime} \mathrm{W} & 0.01 & \end{array}$

In Weddell Abyssal Plain region, near Site 694:

$\begin{array}{llll}10 \mathrm{Feb} & 66^{\circ} 52^{\prime} \mathrm{S} & 33^{\circ} 29^{\prime} \mathrm{W} & 0.06 \\ 11 \mathrm{Feb} & 66^{\circ} 51^{\prime} \mathrm{S} & 33^{\circ} 21^{\prime} \mathrm{W} & 0.01 \\ 12 \mathrm{Feb} & 66^{\circ} 52^{\prime} \mathrm{S} & 33^{\circ} 20^{\prime} \mathrm{W} & 0.02 \\ 13 \mathrm{Feb} & 66^{\circ} 51^{\prime} \mathrm{S} & 33^{\circ} 32^{\prime} \mathrm{W} & 0.02 \\ 14 \mathrm{Feb} & 66^{\circ} 52^{\prime} \mathrm{S} & 33^{\circ} 23^{\prime} \mathrm{W} & 0.12 \\ 15 \mathrm{Feb} & 66^{\circ} 53^{\prime} \mathrm{S} & 33^{\circ} 28^{\prime} \mathrm{W} & 0.03 \\ 16 \mathrm{Feb} & 66^{\circ} 49^{\prime} \mathrm{S} & 33^{\circ} 34^{\prime} \mathrm{W} & 0.01 \\ 17 \mathrm{Feb} & 66^{\circ} 52^{\prime} \mathrm{S} & 33^{\circ} 23^{\prime} \mathrm{W} & 0.04 \\ \text { ean surface chlorophyll } & & 0.04 \pm 0.03 \\ \text { near Site 694: } & & 0.04\end{array}$

In transit to South Orkney Islands region:

$18 \mathrm{Feb} \quad 66^{\circ} 04^{\prime} \mathrm{S} \quad 34^{\circ} 04^{\prime} \mathrm{W} \quad 0.02$

$19 \mathrm{Feb} \quad 64^{\circ} 01^{\prime} \mathrm{S} \quad 38^{\circ} 43^{\prime} \mathrm{W} \quad 0.05$

Near Site 695, South Orkney Islands region:

$\begin{array}{llll}20 \mathrm{Feb} & 62^{\circ} 22^{\prime} \mathrm{S} & 43^{\circ} 31^{\prime} \mathrm{W} & 0.14 \\ 21 \mathrm{Feb} & 62^{\circ} 24^{\prime} \mathrm{S} & 43^{\circ} 23^{\prime} \mathrm{W} & 0.09 \\ \text { 22 Feb } \quad 62^{\circ} 22^{\prime} \mathrm{S} & 43^{\circ} 22^{\prime} \mathrm{W} & 0.01 \\ \text { ean surface chlorophyll } & & \overline{0.08} \pm 0.06 \\ \text { near Site 695: } & & 0.08\end{array}$

20-25 kt winds

13 Jan began a 4-week period of generally light breezes and calm seas

Deploy 1st array, for $23 \mathrm{hr}$

Deploy 2nd array, for $24 \mathrm{hr}$ Deploy 3rd array, for $28 \mathrm{hr}$

Deploy 1st array, for $26 \mathrm{hr}$

Deploy 2nd array, for $44 \mathrm{hr}$ Deploy 3rd array, for $29 \mathrm{hr}$ Deploy 4th array, for $39 \mathrm{hr}$

Deploy 5th array, for $26 \mathrm{hr}$

Deploy 1st array, for $34 \mathrm{hr}$ (windy; swells 2-3 m)

Deploy 2nd array, for $26 \mathrm{hr}$ Deploy 3rd array, for $59 \mathrm{hr}$ (windy; swells 2-3 m)

ND

(Still windy; swells 2-3 m)

ND

(Strong blow; seas up to 6-8 m) Deploy array near 695 , for $29 \mathrm{hr}$ (Wind down to $20 \mathrm{kt}$; seas 2-4 m) 
Table 3 (continued).

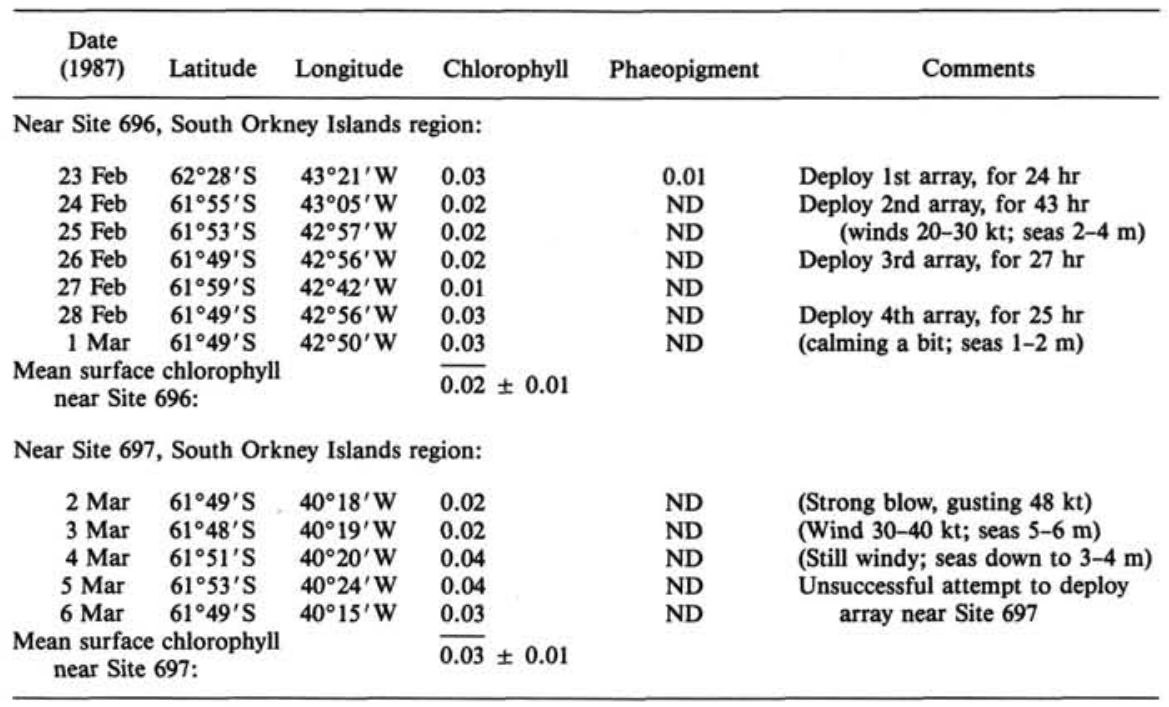

Table 4. Particulate organic content (POC) and its nitrogen and carbon isotopic fractionation for selected samples trapped at $100 \mathrm{~m}$ and $200 \mathrm{~m}$. PON = particulate organic nitrogen. Tabulated values are in milligrams per trap, calculated from 1/8 splits of the total trapped material (or 1/32 split of 100-m sample 113-22-F-S). Sample code lists leg-date-monthtrap depth (S, shallow or D, deep). From Memorial University of Newfoundland.

\begin{tabular}{|c|c|c|c|c|c|}
\hline Sample & $\begin{array}{l}\text { POC } \\
\text { (mg) }\end{array}$ & $\begin{array}{l}\text { PON } \\
\text { (mg) }\end{array}$ & $\begin{array}{c}\mathrm{C} / \mathrm{N} \text { ratio } \\
\text { (mol) }\end{array}$ & $\begin{array}{c}\delta^{15} \mathrm{~N} \\
\text { for PON }\end{array}$ & $\begin{array}{l}\delta^{13} \mathrm{C} \\
\text { for POC }\end{array}$ \\
\hline $113-01-\mathrm{F}-\mathrm{S}$ & ${ }^{\mathrm{a}}(2.15)$ & $(0.47)$ & 5.3 & 0.5 & -30.6 \\
\hline 113-01-F-D & $(0.95)$ & $(0.20)$ & 5.6 & 2.5 & -28.7 \\
\hline $113-02-\mathrm{F}-\mathrm{S}$ & 0.81 & 0.17 & 5.7 & 3.5 & -27.2 \\
\hline 113-02-F-D & & - & - & - & - \\
\hline $113-04-\mathrm{F}-\mathrm{S}$ & (4.78) & $(0.90)$ & 6.2 & 1.0 & -28.9 \\
\hline $113-04-\mathrm{F}-\mathrm{D}$ & (4.30) & $(0.84)$ & 6.0 & 2.3 & -29.3 \\
\hline $113-05-\mathrm{F}-\mathrm{S}$ & $(0.88)$ & $(0.14)$ & 7.7 & $\mathrm{c}$ & -30.8 \\
\hline 113-05-F-D & 2.83 & 0.46 & 7.1 & -0.4 & -28.2 \\
\hline $113-17-\mathrm{F}-\mathrm{S}$ & 1.40 & 0.21 & 7.9 & 2.2 & -28.0 \\
\hline 113-17-F-D & 3.22 & 0.42 & 8.8 & -0.5 & -29.2 \\
\hline $113-22-\mathrm{F}-\mathrm{S}$ & (1.44) & $(0.22)$ & 8.1 & $\mathrm{c}$ & -29.0 \\
\hline $113-22-F-D$ & 0.29 & 0.04 & 9.0 & c & -30.4 \\
\hline 113-24-F-S & 2.25 & 0.27 & 9.6 & -1.1 & -28.3 \\
\hline 113-24-F-D & 0.73 & 0.11 & 7.8 & c & -27.8 \\
\hline 113-26-F-S & 1.67 & 0.35 & 5.6 & -1.2 & -30.1 \\
\hline 113-26-F-D & 0.73 & 0.14 & 5.9 & & -28.3 \\
\hline 113-27-F-S & b & - & - & - & - \\
\hline 113-27-F-D & 2.91 & 0.47 & 7.1 & -2.1 & -28.1 \\
\hline 113-01-M-S & 0.18 & 0.03 & 7.1 & c & -28.4 \\
\hline $113-01-\mathrm{M}-\mathrm{S}$ & 0.58 & & - & - & -27.8 \\
\hline
\end{tabular}

a ( ) Weight of POC or PON is underestimated, for not all of the filtered split was used for isotopic analysis; part of each of these six splits was sacrificed for amino acid analysis (see Table 6).

b Sample lost in combustion.

c Sample too small to determine isotope composition.

Sample lost in purification.

a; and phaeophytin $\mathrm{a}^{\prime}$. In addition, three phaeophorbide-like pigments were found to be present in many of the sediment-trap splits. While their absorption spectra were similar to that of phaeophorbide a, their chromatographic behavior was different in that they eluted after phaeophorbide a (designated as P1). These phaoephorbide a derivatives have been designated on the basis of their polarity as P2, P3, and P4, where P4 is the least polar of the phaeophorbide a-like pigments separated. The HPLC method we employed is not capable of separating zeaxanthin from lutein.
Table 5. Particulate organic nitrogen (PON) flux and its isotopic fractionation. Tabulated values of particulate organic nitrogen are in milligrams per trap, calculated from $1 / 4,1 / 8$, or the average of two 1/16 splits of the total material collected at $100 \mathrm{~m}$ (S) and at $200 \mathrm{~m}$ (D). From Woods Hole Oceanographic Institution.

\begin{tabular}{|c|c|c|c|c|c|}
\hline Sample & Split & $\begin{array}{l}\text { PON } \\
(\mathrm{mg})\end{array}$ & $\begin{array}{c}\mathrm{N} \text { flux } \\
\times 10^{-10} \\
\mathrm{~mol} / \mathrm{cm}^{2} / \mathrm{hr}\end{array}$ & $\begin{array}{c}\delta^{15} \mathrm{~N} \\
\text { for PON }\end{array}$ & $\begin{array}{c}\delta^{15} \mathrm{~N} \\
\text { for } \mathrm{NO}^{3}\end{array}$ \\
\hline $113-18-\mathrm{J}-\mathrm{S}$ & $1 / 4$ & 0.14 & 2.6 & -0.4 & a \\
\hline 113-18-J-D & $1 / 4$ & 0.03 & 0.6 & 3.5 & \\
\hline $113-21-\mathrm{J}-\mathrm{S}$ & $1 / 4$ & 0.07 & 1.3 & 2.9 & a \\
\hline 113-21-J-D & $1 / 4$ & 0.03 & 0.5 & 3.8 & \\
\hline $113-22-\mathrm{J}-\mathrm{S}$ & $1 / 4$ & 0.10 & 1.6 & -0.3 & a \\
\hline $113-22-\mathrm{J}-\mathrm{D}$ & $1 / 4$ & b & b & b & \\
\hline $113-29-\mathrm{J}-\mathrm{S}$ & $1 / 4$ & 0.19 & 3.3 & 2.9 & a \\
\hline 113-29-J-D & $1 / 4$ & b & $\mathrm{b}$ & $b^{2.7}$ & \\
\hline $113-01-\mathrm{F}-\mathrm{S}$ & $1 / 8$ & 0.34 & 3.5 & 0.6 & a \\
\hline $113-01-\mathrm{F}-\mathrm{D}$ & $1 / 8$ & 0.17 & 1.7 & 1.8 & \\
\hline $113-02-\mathrm{F}-\mathrm{S}$ & $1 / 8$ & 0.62 & 9.5 & 0.6 & a \\
\hline 113-02-F-D & $1 / 8$ & 0.25 & 3.8 & 2.1 & \\
\hline $113-04-\mathrm{F}-\mathrm{S}$ & $1 / 8$ & 0.93 & 10.6 & 0.6 & a \\
\hline $113-04-F-D$ & $1 / 8$ & 0.45 & 5.1 & 1.5 & \\
\hline $113-05-\mathrm{F}-\mathrm{S}$ & $1 / 8$ & 1.89 & 31.6 & 0.5 & a \\
\hline 113-05-F-D & $1 / 8$ & ${ }^{c}(0.23)$ & $c^{c}(3.8)$ & 2.6 & \\
\hline $113-11-\mathrm{F}-\mathrm{S}$ & $1 / 4$ & 0.11 & 1.5 & 5.5 & a \\
\hline $113-11-F-D$ & $1 / 4$ & 0.05 & 0.7 & 6.7 & \\
\hline $113-15-\mathrm{F}-\mathrm{S}$ & $1 / 4$ & 0.11 & 1.9 & 4.8 & a \\
\hline $113-15-\mathrm{F}-\mathrm{D}$ & $1 / 4$ & b & b & $b^{4.0}$ & \\
\hline $113-17-\mathrm{F}-\mathrm{S}$ & $1 / 8$ & 0.12 & 0.9 & 7.8 & 7.4 \\
\hline 113-17-F-D & $1 / 8$ & 0.08 & 0.6 & 7.4 & \\
\hline $113-22-\mathrm{F}-\mathrm{S}$ & $1 / 16$ & 3.25 & 50.0 & 1.2 & 10.0 \\
\hline 113-22-F-D & $1 / 8$ & 0.56 & 8.6 & 2.2 & \\
\hline $113-24-\mathrm{F}-\mathrm{S}$ & $1 / 8$ & b & b & 0.7 & 7.6 \\
\hline 113-24-F-D & $1 / 8$ & 0.07 & 1.3 & 1.0 & \\
\hline $113-26-\mathrm{F}-\mathrm{S}$ & $1 / 8$ & 0.13 & 1.4 & 1.3 & 8.1 \\
\hline $113-26-F-D$ & $1 / 8$ & 0.05 & 0.5 & 2.2 & \\
\hline $113-27-\mathrm{F}-\mathrm{S}$ & $1 / 8$ & b & b & $\mathrm{b}$ & 8.0 \\
\hline $113-27-\mathrm{F}-\mathrm{S}$ & $1 / 8$ & 0.11 & 1.8 & 2.0 & \\
\hline $113-01-\mathrm{M}-\mathrm{S}$ & $1 / 8$ & 0.16 & 2.9 & -1.2 & a \\
\hline $113-01-M-D$ & $1 / 8$ & 0.07 & 1.3 & 0.1 & \\
\hline
\end{tabular}

a Surface sample unavailable.

b Sample lost in processing or not analyzed.

( ) Unknown amount of this sample was lost when trap spilled on deck on recovery.

\section{Results}

The HPLC pigment data are reported in units of total nanograms pigment recovered per trap (Table 7). The quantitatively important parent plant pigments measured in the sediment-trap 
Table 6. Amino acid composition of trapped material, determined by subsampling selected 1/8 filtered splits (stations 113-01-F, 113-02-F, 11304-F, and 113-05-F) and a 1/32 filtered split (station 113-22-F). See Tables 4 and 5 for data on total organic content and nitrogen and carbon isotopic composition of these samples.

\begin{tabular}{|c|c|c|c|c|c|c|c|c|c|c|c|c|c|c|c|c|}
\hline Sample & Asp & Thr & Ser & Glu & Gly & Ala & Val & $\begin{array}{l}\text { Amir } \\
(\mu \mathrm{mo} \\
\text { Met }\end{array}$ & $\begin{array}{r}\text { acids } \\
\text { ilter) } \\
\text { Ile }\end{array}$ & Leu & Tyr & Phe & His & Lys & Arg & Total \\
\hline $113-01-\mathrm{F} 100 \mathrm{~m}$ & 0.33 & 0.17 & 0.32 & 0.33 & 0.25 & 0.23 & 0.18 & 0.00 & 0.09 & 0.25 & 0.12 & 0.11 & 0.13 & 0.10 & 0.12 & 2.7 \\
\hline $113-01-\mathrm{F} 200 \mathrm{~m}$ & 0.15 & 0.10 & 0.16 & 0.16 & 0.14 & 0.12 & 0.09 & 0.00 & 0.05 & 0.10 & 0.04 & 0.07 & 0.10 & 0.05 & 0.08 & 1.4 \\
\hline $113-02-\mathrm{F} 200 \mathrm{~m}$ & 0.43 & 0.17 & 0.30 & 0.36 & 0.60 & 0.42 & 0.19 & 0.00 & 0.08 & 0.23 & 0.08 & 0.12 & 0.29 & 0.21 & 0.26 & 3.7 \\
\hline $113-04-\mathrm{F} 100 \mathrm{~m}$ & 0.31 & 0.17 & 0.24 & 0.41 & 0.39 & 0.29 & 0.15 & 0.02 & 0.11 & 0.20 & 0.04 & 0.07 & 0.24 & 0.12 & 0.14 & 2.9 \\
\hline $113-04-\mathrm{F} 200 \mathrm{~m}$ & 0.19 & 0.10 & 0.17 & 0.17 & 0.15 & 0.08 & 0.04 & 0.01 & 0.04 & 0.07 & 0.02 & 0.03 & 0.16 & 0.13 & 0.16 & 1.5 \\
\hline $113-05-\mathrm{F} 100 \mathrm{~m}$ & 0.19 & 0.13 & 0.21 & 0.21 & 0.21 & 0.18 & 0.10 & 0.00 & 0.07 & 0.12 & 0.06 & 0.08 & 0.11 & 0.05 & 0.09 & 1.8 \\
\hline $113-22-\mathrm{F} 100 \mathrm{~m}$ & 0.03 & 0.02 & 0.03 & 0.03 & 0.04 & 0.03 & 0.02 & 0.00 & 0.01 & 0.02 & 0.01 & 0.01 & 0.02 & 0.01 & 0.01 & 0.3 \\
\hline
\end{tabular}

\begin{tabular}{|c|c|c|c|c|c|c|c|c|c|c|c|c|c|c|c|}
\hline \multirow[b]{2}{*}{ Sample } & \multirow[b]{2}{*}{ Asp } & \multirow[b]{2}{*}{ Thr } & \multirow[b]{2}{*}{ Ser } & \multirow[b]{2}{*}{ Glu } & \multirow[b]{2}{*}{ Gly } & \multirow[b]{2}{*}{ Ala } & \multirow[b]{2}{*}{ Val } & \multicolumn{2}{|c|}{$\begin{array}{c}\text { Amino acids } \\
(\%)\end{array}$} & \multirow[b]{2}{*}{ Leu } & \multirow[b]{2}{*}{ Tyr } & \multirow[b]{2}{*}{ Phe } & \multirow[b]{2}{*}{ His } & \multirow[b]{2}{*}{ Lys } & \multirow[b]{2}{*}{ Arg } \\
\hline & & & & & & & & Met & Ile & & & & & & \\
\hline $113-01-\mathrm{F} 100 \mathrm{~m}$ & 12.2 & 6.1 & 11.8 & 12.0 & 9.2 & 8.4 & 6.5 & 0.0 & 3.5 & 9.4 & 4.3 & 4.0 & 4.8 & 3.5 & 4.4 \\
\hline $113-01-\mathrm{F} 200 \mathrm{~m}$ & 10.4 & 6.8 & 11.4 & 11.2 & 9.7 & 8.6 & 6.4 & 0.0 & 3.8 & 7.0 & 3.1 & 5.0 & 7.0 & 3.4 & 6.1 \\
\hline $113-02-\mathrm{F} 200 \mathrm{~m}$ & 11.6 & 4.5 & 8.1 & 9.5 & 16.1 & 11.3 & 5.0 & 0.0 & 2.1 & 6.2 & 2.1 & 3.3 & 7.7 & 5.5 & 7.0 \\
\hline $113-04-\mathrm{F} 100 \mathrm{~m}$ & 10.6 & 5.8 & 8.1 & 14.0 & 13.6 & 9.8 & 5.2 & 0.8 & 3.9 & 7.0 & 1.5 & 2.5 & 8.3 & 4.2 & 4.9 \\
\hline $113-04-\mathrm{F} 200 \mathrm{~m}$ & 12.5 & 6.5 & 10.9 & 11.3 & 9.6 & 5.4 & 2.7 & 0.6 & 2.8 & 4.8 & 1.2 & 1.9 & 10.3 & 8.8 & 10.7 \\
\hline $113-05-\mathrm{F} 100 \mathrm{~m}$ & 10.2 & 7.0 & 11.7 & 11.8 & 11.3 & 9.6 & 5.7 & 0.0 & 4.0 & 6.7 & 3.5 & 4.4 & 5.8 & 3.0 & 5.2 \\
\hline $113-22-\mathrm{F} 100 \mathrm{~m}$ & 11.3 & 7.2 & 11.8 & 10.1 & 12.9 & 9.3 & 5.8 & 0.0 & 3.5 & 8.4 & 3.6 & 3.7 & 5.1 & 2.8 & 4.4 \\
\hline
\end{tabular}

Table 7. Plant pigments and their degradation products trapped at $100 \mathrm{~m}$ and at $200 \mathrm{~m}$, analyzed by High Performance Liquid Chromatography (HPLC). Specific pigments resolved include chlorophyll a; carotene; pheaophorbide + 3 derivatives; phaeophytin a; phaeophytin a'; chlorophyllide a; chlorophyll c; fucoxanthin; 19'-hexanoyloxyfucoxanthin; diadinoxanthin; zeaxanthin + lutein; and chlorophyll b. Depths are S (shallow) $=100 \mathrm{~m} ; \mathrm{D}$ (deep) $=200 \mathrm{~m}$. Tabulated values are in nanograms per trap, calculated from $1 / 4 \mathrm{splits}$ of the total trapped material (or averaged from 1/32 and 1/16 splits, 100-m sample 113-22-F).

\begin{tabular}{|c|c|c|c|c|c|c|c|c|c|c|c|c|c|c|c|c|}
\hline Sample & Depth & (chla) & (car) & (P1) & (P2) & (P3) & (P4) & (pheoa) & (pheoa') & (chlidea) & (chlc) & (fucox) & (h-fuc) & (diad) & (zeax) & (chlb) \\
\hline 113-18-J & $\mathrm{s}$ & 109 & 0 & 0 & 0 & 0 & 0 & 0 & 0 & 0 & 24 & 64 & 0 & 0 & 0 & 0 \\
\hline 113-18-J & D & 67 & 0 & 0 & 0 & 0 & 62 & 0 & 0 & 0 & 0 & 0 & 0 & 0 & 0 & 0 \\
\hline $113-21-\mathrm{J}$ & $\mathrm{s}$ & 121 & 0 & 0 & 0 & 208 & 0 & 0 & 0 & 0 & 0 & 96 & 83 & 0 & 0 & 0 \\
\hline $113-21-\mathrm{J}$ & D & 0 & 0 & 0 & 0 & 0 & 0 & 0 & 0 & 0 & 0 & 0 & 0 & 0 & 0 & 0 \\
\hline $113-22-\mathrm{J}$ & $\mathbf{S}$ & 160 & 0 & 0 & 0 & 36 & 0 & 0 & 0 & 0 & 0 & 199 & 90 & 0 & 0 & 0 \\
\hline $113-22-\mathrm{J}$ & D & 0 & 0 & 0 & 0 & 0 & 0 & 0 & 0 & 0 & 0 & 0 & 0 & 0 & 0 & 0 \\
\hline 113-29-J & S & 1024 & 0 & 306 & 15 & 292 & 282 & 369 & 22 & 62 & 131 & 808 & 251 & 84 & 0 & 0 \\
\hline 113-29-J & D & 1015 & 0 & 1134 & 96 & 189 & 70 & 166 & 45 & 93 & 130 & 1017 & 220 & 113 & 0 & 0 \\
\hline 113-01-F & $\mathrm{s}$ & 6747 & 184 & 1450 & 167 & 3837 & 749 & 617 & 135 & 567 & 1100 & 7858 & 2265 & 699 & 155 & 934 \\
\hline 113-01-F & D & 1839 & 68 & 1992 & 186 & 956 & 137 & 126 & 0 & 180 & 303 & 2421 & 569 & 115 & 40 & 471 \\
\hline $113-02-\mathrm{F}$ & S & 2206 & 0 & 379 & 43 & 1606 & 177 & 209 & 0 & 129 & 232 & 2679 & 965 & 250 & 63 & 368 \\
\hline $113-02-\mathrm{F}$ & D & 493 & 0 & 861 & 61 & 224 & 49 & 0 & 0 & 0 & 41 & 630 & 132 & 0 & 0 & 0 \\
\hline 113-04-F & S & 4504 & 0 & 700 & 65 & 1817 & 272 & 439 & 0 & 315 & 572 & 4287 & 1221 & 291 & 76 & 275 \\
\hline 113-04-F & D & 1892 & 0 & 868 & 54 & 1011 & 147 & 189 & 0 & 161 & 265 & 2437 & 717 & 147 & 57 & 344 \\
\hline $113-05-\mathrm{F}$ & S & 4778 & 0 & 648 & 83 & 1784 & 497 & 425 & 0 & 458 & 694 & 4742 & 1482 & 342 & 86 & 372 \\
\hline $113-05-\mathrm{F}$ & D & 1238 & 0 & 644 & 32 & 412 & 179 & 0 & 0 & 100 & 143 & 1766 & 407 & 83 & 0 & 0 \\
\hline $113-11-\mathrm{F}$ & $\mathrm{S}$ & 337 & 0 & 139 & 0 & 0 & 164 & 0 & 0 & 95 & 0 & 387 & 0 & 0 & 0 & 0 \\
\hline 113-11-F & D & 121 & 0 & 79 & 0 & 0 & 0 & 0 & 0 & 0 & 0 & 116 & 0 & 0 & 0 & 0 \\
\hline 113-15-F & $\mathrm{s}$ & 424 & 0 & 188 & 0 & 35 & 0 & 0 & 0 & 0 & 50 & 512 & 0 & 0 & 0 & 0 \\
\hline $113-15-\mathrm{F}$ & D & 158 & 0 & 190 & 45 & 0 & 0 & 0 & 0 & 0 & 0 & 158 & 0 & 0 & 0 & 0 \\
\hline $113-17-\mathrm{F}$ & $\mathrm{S}$ & 480 & 0 & 218 & 0 & 37 & 53 & 0 & 0 & 0 & 54 & 452 & 0 & 0 & 0 & 0 \\
\hline 131-17-F & D & 132 & 0 & 186 & 0 & 0 & 0 & 0 & 0 & 0 & 0 & 153 & 0 & 0 & 0 & 0 \\
\hline $113-22-\mathrm{F}$ & $S$ & 9337 & 126 & 3319 & 265 & 13077 & 2549 & 1253 & 0 & 297 & 1590 & 10693 & 3979 & 1489 & 137 & 508 \\
\hline $113-22-\mathrm{F}$ & D & 1984 & 63 & 657 & 46 & 2874 & 352 & 241 & 26 & 176 & 306 & 2520 & 820 & 397 & 0 & 0 \\
\hline $113-24-\mathrm{F}$ & $\mathrm{S}$ & 270 & 0 & 0 & 0 & 94 & 106 & 0 & 0 & 0 & 0 & 845 & 433 & 44 & 0 & 0 \\
\hline $113-24-F$ & D & 163 & 0 & 86 & 0 & 99 & 178 & 0 & 0 & 0 & 0 & 1354 & 516 & 42 & 0 & 0 \\
\hline $113-26-\mathrm{F}$ & $\mathrm{S}$ & 246 & 0 & 0 & 0 & 53 & 188 & 0 & 0 & 0 & 0 & 725 & 213 & 0 & 0 & 0 \\
\hline $113-26-\mathrm{F}$ & D & 86 & 0 & 69 & 0 & 0 & 56 & 0 & 0 & 0 & 0 & 381 & 69 & 0 & 0 & 0 \\
\hline $113-27-\mathrm{F}$ & $\mathrm{S}$ & 71 & 0 & 112 & 0 & 0 & 51 & 0 & 0 & 0 & 0 & 813 & 311 & 0 & 0 & 0 \\
\hline 113-27-F & D & 83 & 0 & 0 & 0 & 0 & 64 & 0 & 0 & 0 & 0 & 565 & 380 & 0 & 0 & 0 \\
\hline $113-01-\mathrm{M}$ & $\mathrm{S}$ & 121 & 0 & 25 & 0 & 69 & 134 & 0 & 0 & 0 & 0 & 820 & 293 & 0 & 0 & 0 \\
\hline $113-01-M$ & D & 97 & 0 & 65 & 0 & 22 & 29 & 0 & 0 & 0 & 0 & 637 & 230 & 0 & 0 & 0 \\
\hline
\end{tabular}

splits were the chlorophylls a, b, and c; fucoxanthin; $19^{\prime}$ hexanoyloxyfucoxanthin; and diadinoxanthin. The dominance of the diatom marker pigments (fucoxanthin, diadinoxanthin, and chlorophyll c) indicates that diatoms were an important biomass component of the phytoplankton material collected in the traps. Smaller contributions were provided by chlorophytes (chlorophyll b) and prymnesiophytes (19' hexanoyloxyfucoxanthin). The quantitatively important chlorophyll a derivatives measured were chlorophyllide a (characteristic of chlorophyllase-contain- ing, senescent diatoms); phaeophorbide a (P1); P3; P4; and phaeophytin a.

Pigment loading was generally highest for the upper sediment trap $(100 \mathrm{~m})$ deployed at each of the 16 stations. However, phaeophorbide a (P1) was highest in the lower trap $(200 \mathrm{~m})$ at $62 \%$ of the stations where phaeophorbide a was detectable.

These initial data suggest that phaeophorbide a is a diagenetic end product of chlorophyll a degradation, with chlorophyllide a, P3, P4, and phaeophytin a serving as important in- 
termediates. The ratio of total phaeopigments (in chlorophyll a equivalents) to chlorophyll a was higher in the lower trap at $62 \%$ of the 16 stations examined. The lowest pigment fluxes were measured near Maud Rise Sites 689 and 690.

\section{PARTICLE MORPHOLOGY AND PHYTOPLANKTON SPECIES COMPOSITION}

(Analyses by A. Leventer and R. B. Dunbar)

The samples in general are flocculate in appearance, with microplankton assemblages dominated by diatoms and by the foraminifer Neogloboquadrina pachyderma. Some recognizable fecal pellets are present, although they are far less abundant than in sediment-trap collections from Bransfield Strait (Dunbar, 1984).

We made diatom counts on 14 of the 32 trap samples (10 collections by 100 -m traps and 4 collections by 200 -m traps), which we selected to provide an overview of the maximum variability in the entire data set. Our subsampling procedures have been described previously (Leventer and Dunbar, 1987); for the Leg 113 trap samples, we counted about 500 individuals per sample.

\section{Results}

Our overview taxonomic counts of the diatom species trapped at $100 \mathrm{~m}$ indicate (Table 8):

1. Trapping near Sites 689 and 690 collected a dominantly polar diatom assemblage with some subpolar influence.

2. Trap collections near Site 693 show a neritic influence, having a higher ratio of Nitzschia curta/Nitzschia kerguelensis than do the open-ocean sites. In the McMurdo Sound area of the Ross Sea, we have found $N$. curta to be a good indicator of $\mathrm{pack} / \mathrm{sea}$ ice and ice-edge bloom conditions.

3. In time series trap sampling near Site 693 , there is an interesting floral change from 28 January to 5 February: the percentage of Chaetoceros spp. decreased with time, although it is difficult to separate temporal from spatial variability. This is the only region where Chaetoceros spp. were seen in numerical abundance.

4. Near Site 694, the ratio Thalassiosira spp./N. curta is higher than near Site 693, consistent with a more "open water" assemblage. In the McMurdo Sound area of the Ross Sea, high ratios of Thalassiosira spp./N. curta are a good indicator of open water conditions (unpublished data).

5. The largest amount of phytoplankton was trapped near Site 695 where we recovered a floral assemblage similar to that at the other sites although it was less monospecific than expected.

6. Collections near Site 696 had the highest proportion of Thalassiosira spp. coupled with low $N$. curta, indicative of a summertime "open water" assemblage. Although Site 696 is only a few tens of kilometers from Site 695 , it is in shallower water and closer to land.
Our overview diatom taxonomic counts of four 200-m samples show them to have a diatom species composition very similar to the $100-\mathrm{m}$ samples. While there is microscopic evidence that silica has dissolved between $100 \mathrm{~m}$ and $200 \mathrm{~m}$, there has been no radical change in the sinking floral species assemblage. This is quite different from what we have observed in McMurdo Sound, where large numbers of delicate forms dissolve in the upper $200 \mathrm{~m}$.

\section{ACKNOWLEDGMENTS AND PLANS FOR CONTINUING RESEARCH}

This research was sponsored by National Science Foundation grant DPP-8602762 and by the U.S. Science Advisory Committee to Joint Oceanographic Institutions, Inc. Ship time was provided by the Ocean Drilling Program.

These cooperative drifting sediment-trap collections were continued during the austral summer 1987-88, from the ice-escort vessel Maersk Master which accompanied ODP Leg 119. For this second year of fieldwork in the Indian Ocean sector of the Antarctic, a shallow sediment trap at $50 \mathrm{~m}$ was added to our drifting array, so that we could trap material close to the base of the summer wind-mixed layer as well as at $100 \mathrm{~m}$ and at $200 \mathrm{~m}$.

\section{REFERENCES}

Altabet, M. A., and McCarthy, J. J., 1985. Temporal and spatial variations in the natural abundance of ${ }^{15} \mathrm{~N}$ in PON from a warm-core ring. Deep-Sea Res., 32:755-772.

Bidigare, R. R., Kennicutt, M. C., and Brooks, J. M., 1985. Rapid determination of chlorophylls and degradation products by high-performance liquid chromatography. Limnol. Oceanogr., 30:432-435.

DeMaster, D. J., 1981. The supply and accumulation of silica in the marine environment. Geochim. Cosmochim. Acta, 45:1715-1732.

Dunbar, R. B., 1984. Sediment trap experiments on the antarctic continental margin. Antarctic J. United States, Ann. Res. Iss., 19:70-71.

Dymond, J., Fischer, K., Clauson, M., Cobler, R., Gardner, W., Berger, W., Richardson, M., Soutar, A., and Dunbar, R., 1981. A sediment trap intercomparison study in the Santa Barbara basin. Earth Planet. Sci. Lett., 53:409-418.

Harbison, G. R., and Gilmer, R. W., 1986. Effects of animal behavior on sediment trap collections: implications for the calculation of aragonite fluxes. Deep-Sea Res., 33:1017-1024.

Hare, P. E., 1972. Ion exchange chromatography in lunar organic analyses. Space Life Sci., 3:354-359.

Leventer, A., and Dunbar, R. B. 1987. Diatom flux in McMurdo Sound, Antarctica. Mar. Micropaleontol., 12:49-64.

Macko, S. A., 1981. Stable nitrogen isotope ratios as tracers of organic geochemical processes. [PhD Dissert.]. Univ. Texas at Austin.

Mantoura, R. F., and Llewellyn, C. A., 1983. The rapid determination of algal chlorophyll and carotenoid pigments and their breakdown products in natural waters by reverse-phase high-performance liquid chromatography. Anal. Chim. Acta, 151:297-314.

Parsons, T. R., Maita, Y., and Lalli, C. M., 1985. A Manual of Chemi$\mathrm{cal}$ and Biological Methods for Seawater Analysis. Oxford (Pergamon Press).

Ms 113A-105 
Table 8. Diatom species composition of selected samples (10 collections by 100-m traps plus 4 collections by 200-m traps); tabulated values are number counted/percent of total.

\begin{tabular}{|c|c|c|c|c|c|c|c|c|c|c|c|c|c|c|c|}
\hline & Species & $\begin{array}{c}113-18-\mathrm{J} \\
100 \mathrm{~m}\end{array}$ & $\begin{array}{c}113-18-\mathrm{J} \\
200 \mathrm{~m}\end{array}$ & $\begin{array}{c}113-22-\mathrm{J} \\
100 \mathrm{~m}\end{array}$ & $\begin{array}{l}113-22-\mathrm{J} \\
200 \mathrm{~m}\end{array}$ & $\begin{array}{c}113-29-\mathrm{J} \\
100 \mathrm{~m}\end{array}$ & $\begin{array}{c}113-04-\mathrm{F} \\
100 \mathrm{~m}\end{array}$ & $\begin{array}{c}113-05-\mathrm{F} \\
100 \mathrm{~m}\end{array}$ & $\begin{array}{c}113-15-\mathrm{F} \\
100 \mathrm{~m}\end{array}$ & $\begin{array}{c}113-17-\mathrm{F} \\
100 \mathrm{~m}\end{array}$ & $\begin{array}{c}113-22-\mathrm{F} \\
100 \mathrm{~m}\end{array}$ & $\begin{array}{c}113-22-\mathrm{F} \\
200 \mathrm{~m}\end{array}$ & $\begin{array}{c}113-24-\mathrm{F} \\
100 \mathrm{~m}\end{array}$ & $\begin{array}{c}113-27-\mathrm{F} \\
100 \mathrm{~m}\end{array}$ & $\begin{array}{c}113-27-\mathrm{F} \\
200 \mathrm{~m}\end{array}$ \\
\hline 01 & Actinocyclus actinochilus & & $2 / 0.4$ & $1 / 0.2$ & & $3 / 0.6$ & $2 / 0.4$ & $5 / 1.0$ & & & & $1 / 0.2$ & & & $1 / 0.2$ \\
\hline 02 & Amphiprora spp. & & & & & & & & & & & & & & $4 / 0.8$ \\
\hline 03 & Asteromphalus spp. & $2 / 0.4$ & $5 / 0.9$ & $6 / 1.2$ & $12 / 2.2$ & $3 / 0.6$ & $4 / 0.8$ & & $1 / 0.2$ & $3 / 0.6$ & $5 / 0.9$ & $15 / 3.0$ & $3 / 0.5$ & $1 / 0.2$ & $3 / 0.6$ \\
\hline 04 & Chaetoceros spp. & $14 / 2.6$ & $14 / 2.6$ & $18 / 3.6$ & $25 / 4.7$ & $135 / 24.9$ & $14 / 2.7$ & & $4 / 0.8$ & $1 / 0.2$ & $3 / 0.4$ & & $5 / 0.9$ & $3 / 0.6$ & $1 / 0.2$ \\
\hline 05 & Corethron criophylum & $2 / 0.4$ & $1 / 0.2$ & $4 / 0.8$ & $10 / 1.9$ & $7 / 1.3$ & $1 / 0.2$ & $1 / 0.2$ & $1 / 0.2$ & $5 / 0.9$ & $2 / 0.4$ & & $2 / 0.4$ & $2 / 0.4$ & $2 / 0.4$ \\
\hline 06 & Coscinodiscus furcatus & & & & & $1 / 0.2$ & & & & & & & & & \\
\hline 07 & C. rothi var. stelliger & $1 / 0.2$ & & & & & $1 / 0.2$ & & & & & & & & \\
\hline 08 & Eucampia antarctica & $1 / 0.2$ & $1 / 0.2$ & & & & & $1 / 0.2$ & & $1 / 0.2$ & $2 / 0.4$ & & & & \\
\hline 09 & Fragillaria islandica & & $4 / 0.8$ & & $10 / 1.9$ & $1 / 0.2$ & & & $5 / 0.9$ & & & & $1 / 0.2$ & & \\
\hline 10 & Navicula spp. & $3 / 0.6$ & & & & $2 / 0.4$ & & & $2 / 0.4$ & & $1 / 0.2$ & & & & \\
\hline 11 & Nitzschia angulata & $42 / 7.9$ & $15 / 2.7$ & $46 / 9.3$ & $19 / 3.6$ & $10 / 1.8$ & $14 / 2.7$ & $19 / 3.7$ & $13 / 2.5$ & $23 / 4.5$ & $56 / 10.1$ & $51 / 10.2$ & $47 / 8.3$ & $43 / 8.2$ & $36 / 6.9$ \\
\hline 12 & N. curta & $165 / 31.0$ & $198 / 36.3$ & $178 / 35.8$ & $220 / 41.2$ & $211 / 38.9$ & $254 / 48.6$ & $225 / 43.8$ & $153 / 29.0$ & $84 / 16.3$ & $147 / 26.6$ & $119 / 23.8$ & $73 / 13.0$ & $71 / 13.5$ & $74 / 14.1$ \\
\hline 13 & N. cylindrus & $6 / 1.1$ & $23 / 4.2$ & $1 / 0.2$ & $15 / 1.9$ & $2 / 0.4$ & & $23 / 4.5$ & $81 / 15.4$ & $90 / 17.4$ & $31 / 5.6$ & & & $2 / 0.4$ & \\
\hline 14 & N. gruendleri (antarctica) & & & & & & $1 / 0.2$ & $1 / 0.2$ & & & & & $2 / 0.4$ & & \\
\hline 15 & N. kerguelensis & $168 / 31.5$ & $162 / 29.7$ & $118 / 23.7$ & $135 / 25.3$ & $41 / 7.6$ & $59 / 11.3$ & $77 / 15.0$ & $106 / 20.1$ & $134 / 26.0$ & $44 / 8.0$ & $33 / 6.6$ & $102 / 18.1$ & $86 / 16.3$ & $115 / 21.9$ \\
\hline 16 & N. obiquecostata & & & & $1 / 0.2$ & & $3 / 0.6$ & $2 / 0.4$ & & & $4 / 0.7$ & $10 / 2.0$ & & & \\
\hline 17 & N. ritscheri & $2 / 0.4$ & $1 / 0.2$ & $2 / 0.4$ & $1 / 0.2$ & $3 / 0.6$ & $23 / 4.4$ & $17 / 3.3$ & & $5 / 1.0$ & $3 / 0.4$ & $18 / 3.6$ & $2 / 0.4$ & $1 / 0.2$ & $1 / 0.2$ \\
\hline 18 & N. sublinearis & & $1 / 0.2$ & & & $1 / 0.2$ & $10 / 1.9$ & $13 / 2.5$ & $2 / 0.4$ & $1 / 0.2$ & $6 / 1.1$ & $5 / 1.0$ & $6 / 1.1$ & & $3 / 0.6$ \\
\hline 19 & N. spp. & $9 / 1.7$ & & $9 / 1.8$ & $4 / 0.7$ & $50 / 9.2$ & $55 / 10.5$ & $27 / 5.3$ & $20 / 3.8$ & $11 / 2.1$ & $63 / 11.4$ & $73 / 14.6$ & $27 / 4.8$ & $15 / 2.8$ & $20 / 3.8$ \\
\hline 20 & Pleurosigma spp. & $3 / 0.6$ & & & & $1 / 0.2$ & & & & & $2 / 0.4$ & & & & \\
\hline 21 & Porosira pseudodenticulata & $3 / 0.6$ & $2 / 0.4$ & & & $4 / 0.7$ & $1 / 0.2$ & $1 / 0.2$ & & & & & & & \\
\hline 22 & Rhizosolenia spp. & $3 / 0.6$ & & $10 / 2.0$ & $4 / 0.7$ & $6 / 1.1$ & $7 / 1.3$ & $3 / 0.6$ & $2 / 0.4$ & $1 / 0.2$ & $2 / 0.4$ & & $1 / 0.2$ & $2 / 0.4$ & \\
\hline 23 & Thalassiosira gracilis & $4 / 0.8$ & $6 / 1.1$ & $18 / 3.6$ & & $7 / 1.3$ & $7 / 1.3$ & & & & & $5 / 1.0$ & & & \\
\hline 24 & T. lentiginosus & $2 / 0.4$ & & & & & & $1 / 0.2$ & $1 / 0.2$ & & & & & & \\
\hline 25 & T. oliveriana & $4 / 0.8$ & $4 / 0.8$ & $1 / 0.2$ & $4 / 0.7$ & $1 / 0.2$ & $3 / 0.6$ & $1 / 0.2$ & $2 / 0.4$ & $1 / 0.2$ & $5 / 0.9$ & $2 / 0.4$ & $4 / 0.7$ & $1 / 0.2$ & $3 / 0.6$ \\
\hline 26 & T. tumida & & & & & & & & & & & $6 / 1.2$ & & & \\
\hline 27 & $T$ spp. & $75 / 14.1$ & $101 / 18.5$ & $60 / 12.1$ & $66 / 12.4$ & $42 / 7.7$ & $56 / 10.7$ & $79 / 15.4$ & $128 / 24.3$ & $156 / 30.2$ & $173 / 31.3$ & $144 / 28.8$ & $286 / 50.8$ & $300 / 56.9$ & $260 / 49.5$ \\
\hline 28 & Tropidoneis spp. & $\begin{array}{r}1 / 0.2 \\
23 / 4.3\end{array}$ & $2 / 0.4$ & $\begin{array}{r}1 / 0.2 \\
16 / 3.2\end{array}$ & $\begin{array}{l}6 / 1.1 \\
2 / 0.4\end{array}$ & $\begin{array}{l}2 / 0.4 \\
9 / 1.7\end{array}$ & & & $1 / 0.2$ & $3 / 0.6$ & & $9 / 18$ & $1 / 02$ & & $2 / 04$ \\
\hline \multirow[t]{2}{*}{30} & $\begin{array}{l}\text { unknown pennates } \\
\text { unknown centrics }\end{array}$ & $\begin{array}{r}23 / 4.3 \\
6 / 1.1\end{array}$ & & $\begin{array}{r}16 / 3.2 \\
8 / 1.6\end{array}$ & $\begin{array}{l}2 / 0.4 \\
1 / 0.2\end{array}$ & & $\begin{array}{l}7 / 1.3 \\
1 / 0.2\end{array}$ & & $1 / 0.2$ & $3 / 0.6$ & $6 / 1.1$ & $\begin{array}{l}9 / 1.8 \\
9 / 1.8\end{array}$ & $\begin{array}{l}1 / 0.2 \\
1 / 0.2\end{array}$ & & $2 / 0.4$ \\
\hline & Total counted & 533 & 546 & 497 & 534 & 542 & 523 & 514 & 527 & 516 & 553 & 500 & 563 & 527 & 525 \\
\hline
\end{tabular}

